\title{
Lipopolysaccharide-Induced Necroptosis of Brain Microvascular Endothelial Cells Can Be Prevented by Inhibition of Endothelin Receptors
}

\author{
Y. ABDUL ${ }^{1}$, R. WARD ${ }^{2}$, G. DONG ${ }^{1}$, A. ERGUL ${ }^{1,3}$ \\ ${ }^{1}$ Department of Physiology, Augusta University, Augusta, GA, USA, ${ }^{2}$ Department of Neuroscience \\ and Regenerative Medicine, Augusta University, Augusta, GA, USA, ${ }^{3}$ Charlie Norwood Veterans \\ Affairs Medical Center, Augusta, GA, USA
}

Received December 18, 2017

Accepted March 9, 2018

\section{Summary}

Over activation of the endothelin-1 (ET-1) system in disease states contributes to endothelial dysfunction. On the other hand, ET-1 promotes proliferation and survival of endothelial cells. Regulation of programmed cell death (PCD) pathways is critical for cell survival. Recently discovered necroptosis (regulated necrosis) is a pathological PCD mechanism mediated by the activation of toll like receptor 4 (TLR4), which also happens to stimulate ET-1 production in dendritic cells. To establish the effect of ET-1 on PCD and survival of human brain microvascular endothelial cells (BMVECs) under control and inflammatory conditions, BMVECs were treated with ET-1 (10 nM, $100 \mathrm{nM}$ and $1 \mu \mathrm{M}$ ) or lipopolysaccharide (LPS, $100 \mathrm{ng} / \mathrm{ml}$ ). ET receptors were blocked with bosentan $(10 \mu \mathrm{M})$. Under normal growth conditions, exogenous ET-1 reduced BMVEC viability and migration at a relatively high concentration $(1 \mu \mathrm{M})$. This was accompanied with activation of necroptosis and apoptosis marker genes. LPS decreased endogenous ET-1 secretion, increased $\mathrm{ET}_{\mathrm{B}}$ receptor expression and activated necroptosis. Even though ET-1 levels were low (less than $10 \mathrm{nM}$ levels used under normal growth conditions), blocking of ET receptors with bosentan inhibited the necroptosis pathway and improved the cell migration ability of BMVECs, suggesting that under inflammatory conditions, ET-1 activates PCD pathways in BMVECs even at physiological levels.

\section{Key words}

LPS • Necroptosis • Apoptosis • Ferroptosis • Endothelin

\section{Corresponding author}

A. Ergul, Department of Physiology, Augusta University, 1120 15th Street CA-2094, Augusta, GA 30912, USA. Fax: 706-7217299. E-mail: aergul@augusta.edu

\section{Introduction}

Brain is a unique organ, which has no energy reserves and requires constant blood supply for proper function (Iadecola 2017). To meet this high demand, it is a highly vascularized organ with a capillary bed that runs approximately 400-miles long (Begley et al. 2003, Cipolla 2009). Thus, regulation of cerebrovascular structure, integrity and function is of utmost importance for cerebral perfusion. In this regard, brain microvascular endothelial cells (BMVECs) are fundamentally important as they participate in the formation of 1) the neurovascular unit, which provides direct communication between neurons, glial cells and the vasculature, and 2) blood brain barrier, which separates the brain from circulating blood. In many disease states, especially under inflammatory conditions, BMVECs are an early target thus; better understanding of the cell survival/death properties can identify mechanisms to improve endothelial function and integrity. Recent advances in the field of programmed cell death (PCD) studies showed that in addition to apoptosis, caspase-independent pathways such as necroptosis and ferroptosis are also involved in cell death processes in different cell types (Dixon et al. 2012, Linkermann et al. 2014, Xie et al. 2016, Yu et al. 2017). However, whether these PCD pathways occur in BMVECs remained unknown.

It is well established that ET-1 contributes to cerebrovascular dysfunction and remodeling in different disease states. Experimental data suggests that endothelial ET-1 secretion occurs mainly toward the medial layer 
(Wagner et al. 1992) and the vascular effects observed could be due to mostly paracrine and autocrine functions, rather than endocrine effects. ET-1 promotes endothelial cell survival and prevents apoptosis in an autocrine manner (Cifarelli et al. 2012). Anti-apoptotic action of ET-1 is also observed in cardiac myocytes (Ogata et al. 2003) and human umbilical vein endothelial cells (Dong et al. 2005). Furthermore, ET-1 induces angiogenic responses in cultured endothelial cells through $\mathrm{ET}_{\mathrm{B}}$ receptors and stimulates neovascularization in vivo in concert with VEGF (Morbidelli et al. 1995, Salani et al. 2000). We have shown that dual blockade of $\mathrm{ET}_{\mathrm{A}}$ and $\mathrm{ET}_{\mathrm{B}}$ receptors with bosentan reverses diabetes-mediated pathological neovascularization in the brain (Abdelsaid et al. 2014). On the other hand, ET-1 can cause apoptosis of endothelial progenitor cells in a hypertension model (Chen et al. 2012). However, the effect of ET-1 on different cell death pathways in BMVECs, especially under inflammatory conditions is not studied. Thus, the objective of current study was to investigate the role of ET-1/ET receptors on survival and PCD pathways in BMVECs.

\section{a. Schematic of Experimental Design}

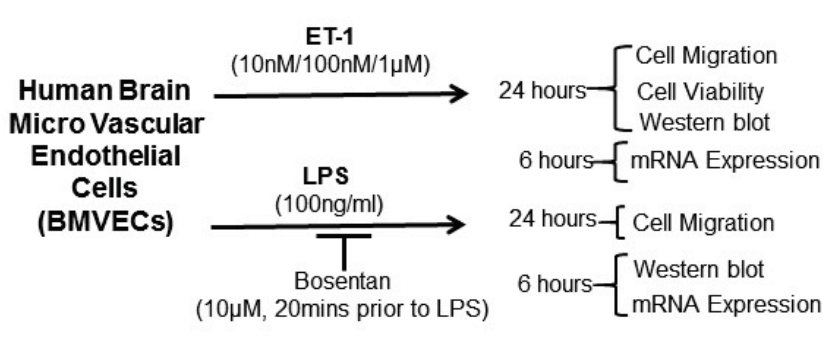

\section{Materials and Methods}

\section{BMVEC culture and treatments}

Experiments were performed using immortalized human brain microvascular endothelial cells known as HBEC-5i (ATCC-CRL3245). Cells were gown in endothelial growth media (VEC technologies, Rensselaer, NY, USA) and plated on flasks coated with $0.1 \%$ gelatin. VEC is a complete media containing FBS, antibiotics and growth factors (concentration details are not provided by manufacturer on the data sheets). Cells were grown to $80-90 \%$ confluency and passage 5-8 were used in current experiments. Cells were serum starved in Dulbecco's Modified Eagle's medium (DMEM) for $2 \mathrm{~h}$ and treated with drugs in $2 \%$ FBS containing DMEM. Cells were treated with various concentrations of ET-1 $(0,10 \mathrm{nM}$, $100 \mathrm{nM}$ or $1 \mu \mathrm{M}$ ) or lipopolysaccharide (LPS, $100 \mathrm{ng} / \mathrm{ml}$ ) for $24 \mathrm{~h}$ and viability and cell death pathways were assessed as described below and on Figure 1a. To determine the role of ET-1 in LPS-induced cell death, cells were preincubated with bosentan $(10 \mu \mathrm{M}) 20 \mathrm{~min}$ before LPS challenge. For gene expression studies, cells were harvested $6 \mathrm{~h}$ after stimulation.

\section{b. Primer Sequences for qRT-PCR}

Gene

Human TLR-4

Human RIPK3

Human Caspase-3

Human IREB2

Human GAPDH
Primer Sequence

Forward- CGTGGAGACTTGGCCCTAAA Reverse- AGCAATGGAATAGGGGTGAA Forward- ACCTTCCAGCCTGATGTCGT Reverse- TGACCTCCCTGGATATCGCC

Forward- TGGAATGTCCTGGGACACCG Reverse- ACCGAGATGTCATTCCAGTGC

Forward- ACGCCCCAAAAGCAGGATAC Reverse- GCAGAACATCATACTTGGTGCC Forward- CTCTGCTCCTCCTGTTCGAC Reverse- GCGCCCAATACGACCAAATC

Fig. 1. Schematic representation of experimental design. a) Primer sequences used in qRT-PCR and b) endpoints measured after ET-1 and LPS treatment.

\section{Cell viability assay \\ Cell viability was measured by RealTime}

Glo-MT Viability Assay kit (Promega, Madison, WI, USA). Briefly, BMVECs were grown to $80-90 \%$ confluency in a 96-well plate. Media was replaced with low FBS ( $2 \%$ FBS) containing DMEM and allowed to stabilize for $4 \mathrm{~h}$. Reagents in kit were prepared according to manufacturer's instructions. MT cell viability assay substrate and NanoLuc enzyme were diluted with test compounds (10 nM, $100 \mathrm{nM}, 1 \mu \mathrm{M}$ ET-1 and $100 \mathrm{ng} / \mathrm{ml}$
LPS) in media and cells were treated for $24 \mathrm{~h}$. Luminescence was measured at 1, 2, 3, 6, 9, 12 and $24 \mathrm{~h}$ after treatment. Relative luminescence unit (RLU) was plotted against time in hours. Time at $50 \%$ of the cells were viable (t50) was determined.

\section{Cell migration assay}

Cell migration assay (wound healing) was performed as described before (Abdelsaid et al. 2013). Briefly, BMVECs were grown to confluence on a 12-well 
plate. Monolayer was wounded with a single sterile cell scraper of fixed diameter. Images of wounded areas were taken before treatment with test compounds and after $24 \mathrm{~h}$. Cell migration was calculated by measuring migration distance normalized to initial distance of the wound using AxioObserver Zeiss Microscope software and data is expressed as the percentage of untreated control cells.

\section{Western blot analysis}

PCD pathways were assessed by measuring protein levels of phospho(p)RIP3, IREB-2, and caspase-3 as markers for necroptosis, ferroptosis and apoptosis, respectively. Briefly, equivalent amounts of cell lysates of BMVECs $(20 \mu \mathrm{g}$ protein/lane) were loaded onto $10 \%$ SDS-PAGE, proteins separated, and proteins transferred to nitrocellulose membranes. The membranes were blocked with $5 \%$ bovine serum albumin followed by incubation for $12 \mathrm{~h}$ at $4{ }^{\circ} \mathrm{C}$ with primary antibody anti-toll like receptor-4 (TLR-4, ab22048, Abcam, Cambridge, MA, USA), anti-phosho(p)RIP3 (ab209384, Abcam), anti-MyD88 (4283, Cell Signaling Tech., Danvers, MA, USA), anti-IREB2 (ab106296, Abcam), anti-caspase-3 (9662, Cell Signaling Tech.), anti-ET $\mathrm{A}_{\mathrm{A}}$ receptor (ab85163, Abcam) or anti-ET $T_{\mathrm{B}}$ receptor (AER002, Alomone labs, Jerusalem, Israel) at 1:1,000 dilution or anti $\beta$-actin at 1:3,000 dilution. After washing, membranes were incubated for $1 \mathrm{~h}$ at $20^{\circ} \mathrm{C}$ with appropriate secondary antibodies (horseradish peroxidase [HRP]-conjugated; dilution 1:3,000). Pre-stained molecular weight markers were run in parallel to identify the molecular weight of proteins of interest. For chemiluminescent detection, the membranes were treated with enhanced chemiluminescent reagent and the signals were monitored on Alpha Imager (Alpha Innotech, San Leandro, CA, USA). Relative band intensity was determined by densitometry software (Alpha Innotech, ProteinSimple, San Jose, CA, USA) and normalized with $\beta$-actin protein.

\section{Quantitative real time PCR ( $q R T-P C R)$}

BMVECs were lysed in RNA lysis buffer and RNA was isolated using SV Total RNA isolation system (Promega, USA). Quality and quantity of extracted RNA was assayed using a Nanodrop instrument (NanoDrop Technologies, Wilmington, DE, USA). iScript cDNA synthesis kit (cat \#1708891, BioRad, Foster City, CA, USA) was used to reverse transcribe equal quantities of total RNA following the manufacturer's instructions. Primers were custom designed from Invitrogen (Thermo
Fisher Scientific, Grand Island, NY, USA). The sequences of primers used in the study are listed in Figure 1b. qRT-PCR was performed using iScript Reverse Transcription super mix (cat \#1708840, Biorad, Foster City, CA, USA) and StepOnePlus Real-Time PCR System (Thermo Fisher Scientific) as per the manufacturer's protocol. The relative gene expression was analyzed by the delta-delta $\mathrm{Ct}$ method using GAPDH as endogenous control gene and normalized to the respective control group.

\section{ET-1 ELISA}

BMVECs were incubated with LPS $(100 \mathrm{ng} / \mathrm{ml})$ for $6 \mathrm{~h}$. Media was collected and ET-1 was measured using commercially available ELISA kit (ab10072, Abcam) following the manufacturer's instruction. Results were normalized with total protein in cell lysate and expressed as $\mathrm{pg} / \mathrm{mg}$ protein.

\section{Data analysis}

One-way ANOVA was used to analyze data with multiple groups and followed by a Tukey's post hoc comparison. Student t-test was used to compare data with only two groups. Data was expressed as mean \pm SEM. $\mathrm{p}<0.05$ was considered significant.

\section{Results}

\section{ET-1 lowers cell survival at high but not low concentrations} BMVECs were incubated with ET-1 $(10 \mathrm{nM}$, $100 \mathrm{nM}$ or $1 \mu \mathrm{M})$ for $24 \mathrm{~h}$ and cell viability was measured as relative luminescence unit (RLU) at different time points (Fig. 2a). Time required for $50 \%$ reduction in viability (t50) was different among the groups (Fig. 2b, $\mathrm{p}=0.0025)$. Post hoc analysis indicated that $1 \mu \mathrm{M}$ ET-1 significantly reduced the t50. Cell migration, an assay to assess the angiogenic properties of BMVECs, showed similar results. $1 \mu \mathrm{M}$ ET-1 significantly reduced the cell migration of BMVECs (Fig. 2d).

PCD markers including pRIPK3 (necroptosis), cleaved caspase-3 (apoptosis) and IREB2 (ferroptosis) were assessed in cell lysates after $24 \mathrm{~h}$ of ET-1 treatment. None of the marker proteins was different between the groups (Figs 3a-3c). However, mRNA expression after $6 \mathrm{~h}$ of ET-1 treatment showed differences (Fig. 4). Post hoc analysis indicated that TLR-4 mRNA was significantly higher in cells treated with $1 \mu \mathrm{M}$ ET-1 (Fig. 4a). Expression of RIPK3 decreased with 10 and $100 \mathrm{nM}$ ET-1 but increased with $1 \mu \mathrm{M}$ ET-1 treatment 
(Fig. 4b). Apoptotic marker caspase-3 was reduced with the low and moderate dose of ET-1 (Fig. 4c). In contrast, $1 \mu \mathrm{M}$ ET-1 upregulated the caspase-3 gene expression. We did not observe any changes in mRNA expression of IREB2 (Fig. 4d).

\section{ET receptor inhibition reduced the LPS-mediated PCD in} BMVECS

LPS $(100 \mathrm{ng} / \mathrm{ml})$ treatment for $6 \mathrm{~h}$ increased the mRNA levels of TLR-4 $(\mathrm{p}<0.05)$ (Fig. 5a). While it was not significant, LPS had the most effect on RIPK3, mRNA expression (Fig. 5b).

a.

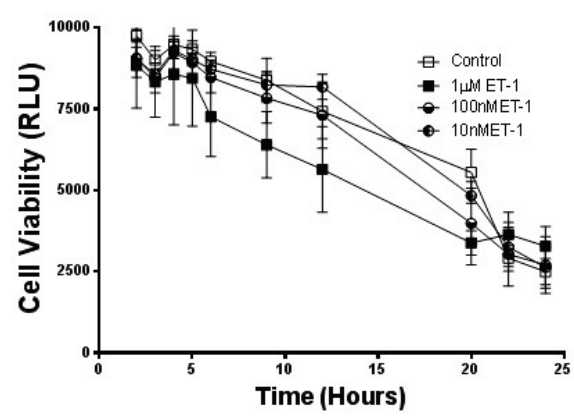

b.

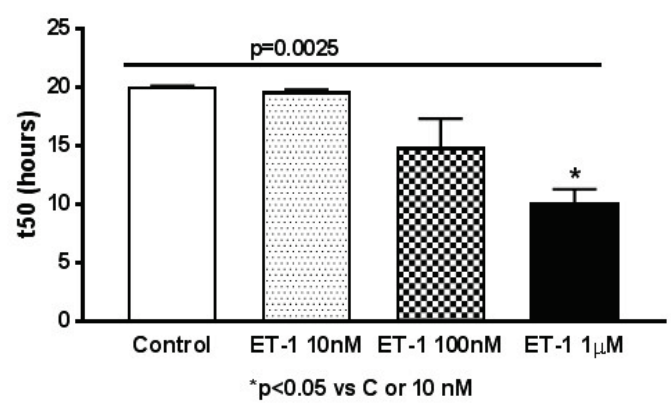

LPS treatment reduced ET-1 secretion (Fig. 6). BMVECs expressed the $\mathrm{ET}_{\mathrm{A}}$ receptor and its expression did not change with LPS treatment, whereas $\mathrm{ET}_{\mathrm{B}}$ receptor expression was increased significantly (Figs 6b and 6c). LPS treatment also increased TLR-4 protein as measured by immunoblotting (Fig. 7a). Preincubation of BMVECs with ET receptor blocker bosentan reduced the expression of TLR-4 as well as downstream signaling partners Myd88 and phosphoRIPK3 proteins (Figs 7b and 7c). Additionally, inhibition of ET receptors improved the migration of BMVECs after LPS treatment (Fig. 7d, p<0.001).

c.

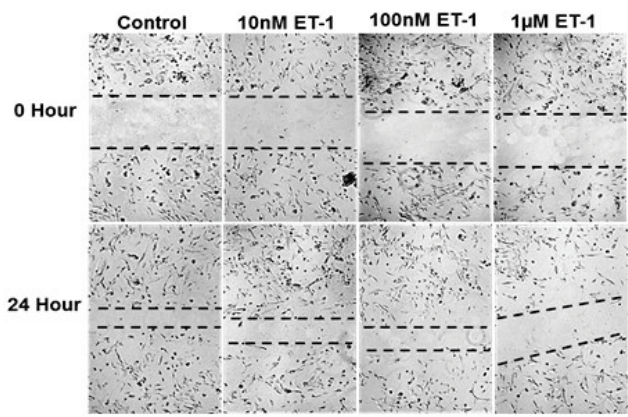

d.

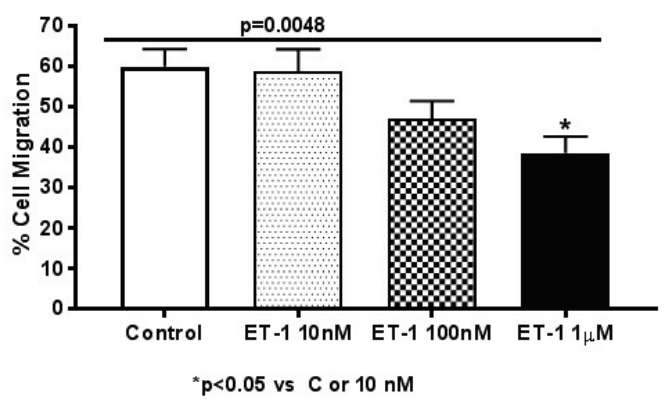

Fig. 2. Exogenous ET-1 stimulation lowers BMVEC viability and cell migration at high concentrations. BMVECs were treated with $10 \mathrm{nM}$, $100 \mathrm{nM}$ or $1 \mu \mathrm{M} \mathrm{ET}-1$ for $24 \mathrm{~h}$ and a) cell viability was measured as relative luminescence (RLU) for $24 \mathrm{~h}$ and b) time at $50 \%$ viable cells (t50) was calculated $1 \mu \mathrm{M}$ dose of ET-1 have significant reduction in t50 (* $p<0.05$ vs. control or $10 \mathrm{nM}$ ET-1). Cell migration was measured by scratch assay $\mathbf{c}$ ) and $\mathbf{d}$ ) it was significantly reduced with $1 \mu \mathrm{M}$ dose of ET-1 (* $p<0.05$ vs. control or $10 \mathrm{nM}$ ET-1, $\mathrm{n}=4-6)$.

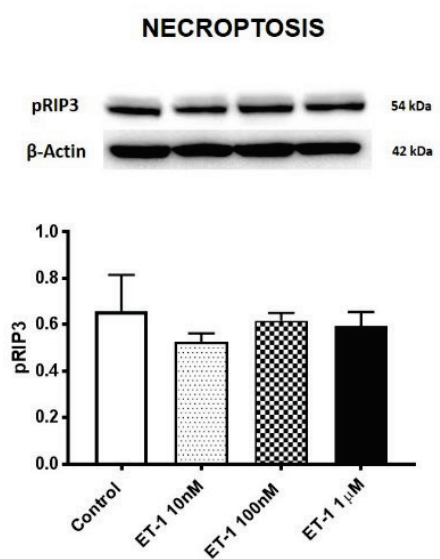

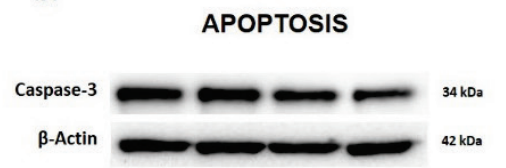

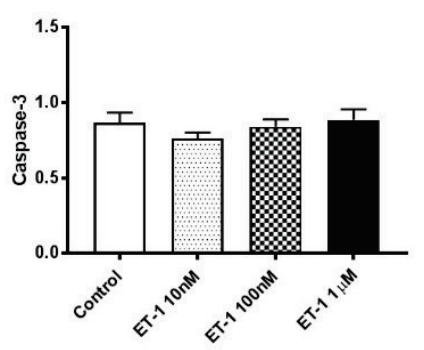

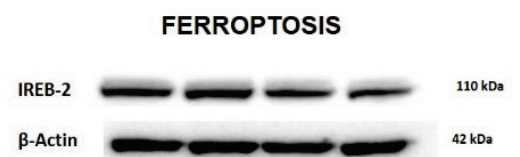

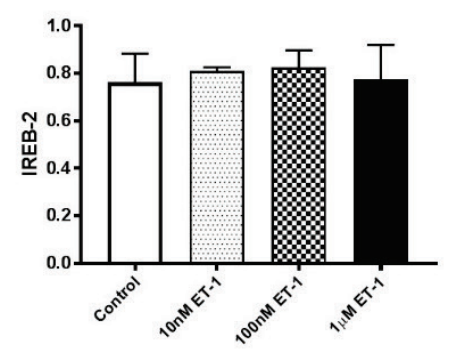

Fig. 3. Programmed cell death (PCD) marker proteins were not different after $24 \mathrm{~h}$ of ET-1 treatment. a) Necroptosis (pRIPK3), b) apoptosis (caspase-3) and c) ferroptosis (IREB2) proteins were measured in cell lysate after $24 \mathrm{~h}$ of ET-1 treatment. There was no significant difference in any of these marker proteins $(n=3-4)$. 


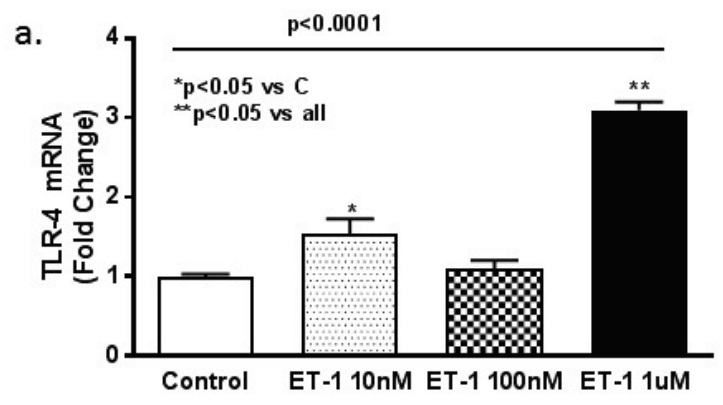

b.
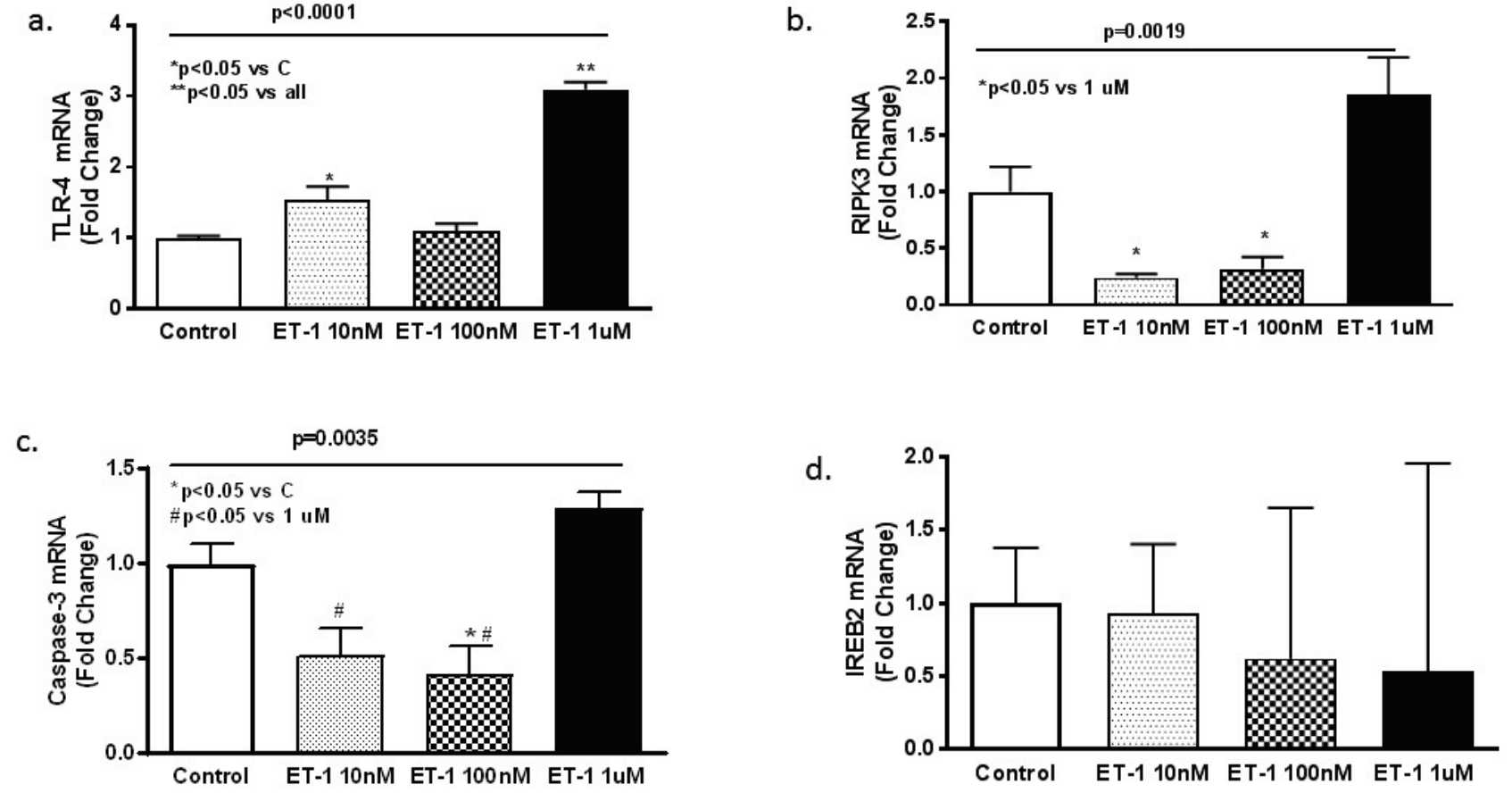

Fig. 4. ET-1 has dose dependent regulation of programmed cell death (PCD) marker genes on BMVECs measured after $6 \mathrm{~h}$. Necroptosis marker gene a) TLR-4 was upregulated with $10 \mathrm{nM} \mathrm{ET-1}\left({ }^{*} \mathrm{p}<0.05\right.$ vs. control) and $1 \mu \mathrm{M} \mathrm{ET}-1$ (** $\mathrm{p}<0.05$ vs. all groups, $\left.n=3-4\right)$, while b) RIPK3 was significantly upregulated with $1 \mu \mathrm{M}$ dose of ET-1 (* $\mathrm{p}<0.05$ vs. control). Apoptosis marker gene c) caspase-3 was down regulated with $10 \mathrm{nM}$ and $100 \mathrm{nM} \mathrm{ET}-1$ (* $\mathrm{p}<0.05 \mathrm{vs}$. control); however, it was upregulated with the $1 \mu \mathrm{M}$ ET-1 (\# $\mathrm{p}<0.05 \mathrm{vs}$. $10 \mathrm{nM}$ or $100 \mathrm{nM}$ ET-1, $\mathrm{n}=3)$. Ferroptosis marker gene d) IREB2 expression was not different between the groups $(\mathrm{n}=3)$.

a.

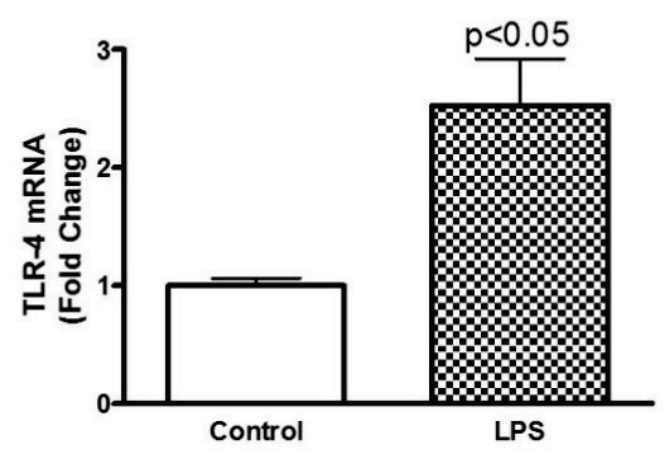

c.

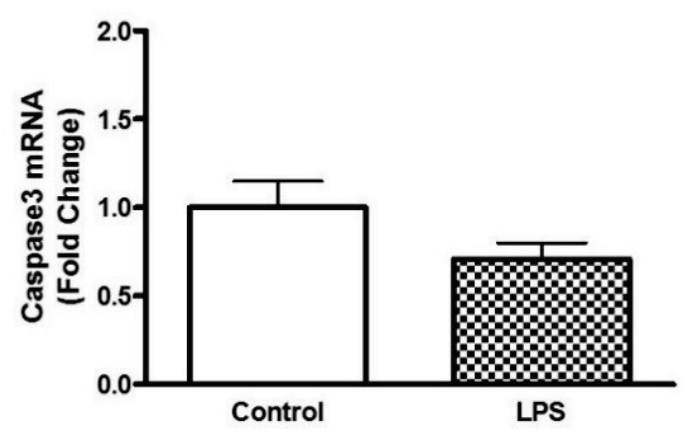

b.

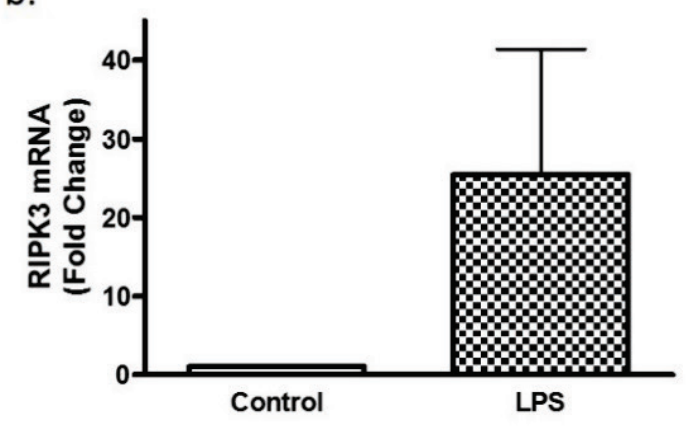

d.

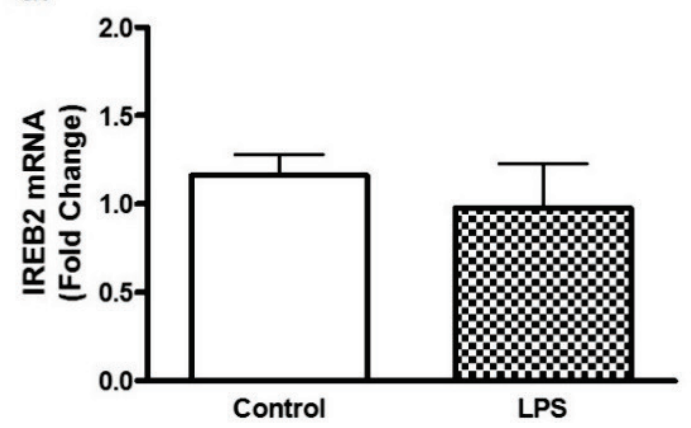

Fig. 5. LPS treatment for $6 \mathrm{~h}$ upregulate the necroptosis marker genes. a) TLR-4 gene was upregulated with the LPS (100 $\mathrm{ng} / \mathrm{ml})$ treatment ( $* \mathrm{p}<0.05$ vs. control). b) RIPK3 gene was also upregulated with LPS treatment. c) Apoptosis (caspase-3) and d) ferroptosis (IREB2) marker genes were not different between LPS and control group $(n=4-6)$. 


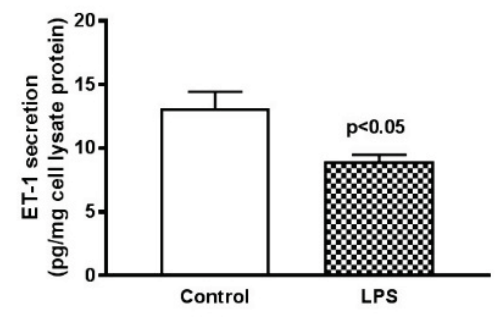

b.

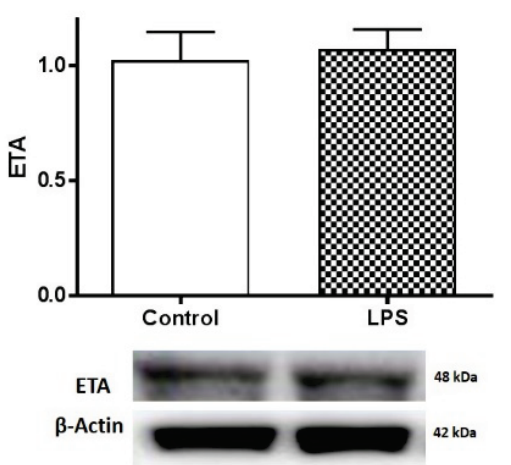

c.

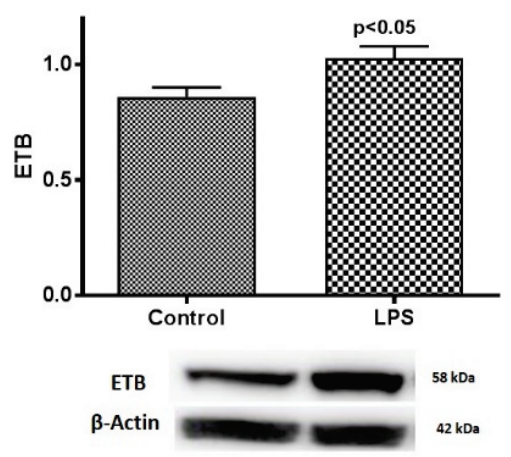

Fig. 6. LPS treatment can modulate the ET system in BMVECs. a) Secreted ET-1 measured in media was significantly reduced with LPS $(100 \mathrm{ng} / \mathrm{ml})$ treatment $(* \mathrm{p}<0.05 \mathrm{vs}$. control, $\mathrm{n}=3)$. b) $\mathrm{ET}_{\mathrm{A}}$ receptor expression was measured in cell lysate and it was not different between the groups, while expression of $\mathbf{c}) \mathrm{ET}_{\mathrm{B}}$ receptor was significantly increased with the LPS treatment (* $\mathrm{p}<0.05$ vs. control, $n=4-6)$.

a.

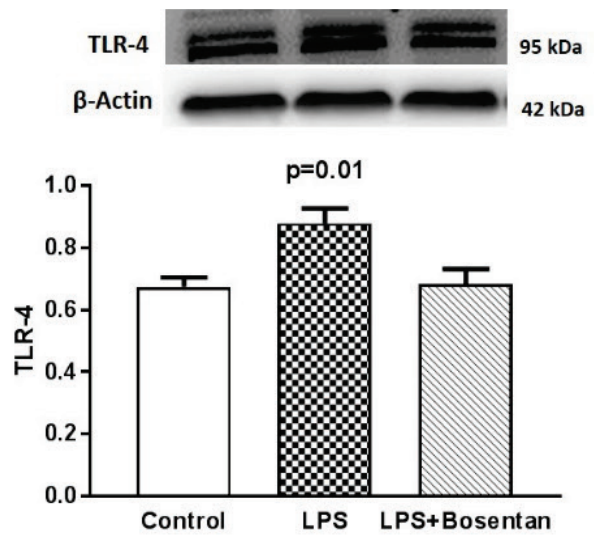

C

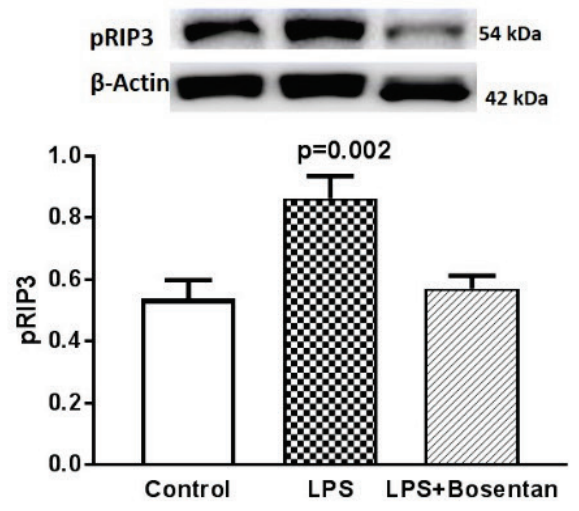

b.

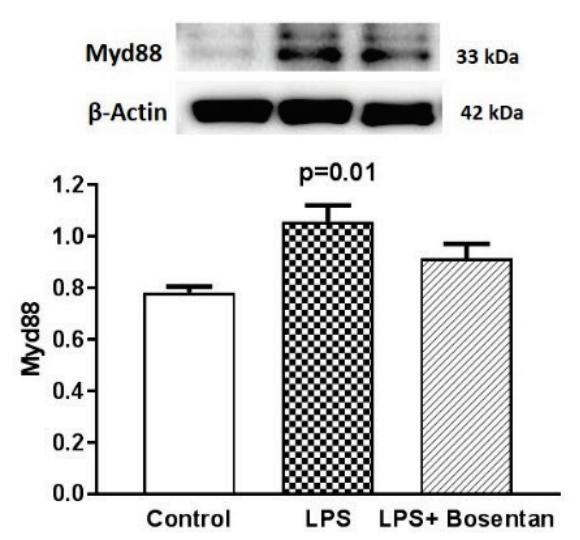

d.

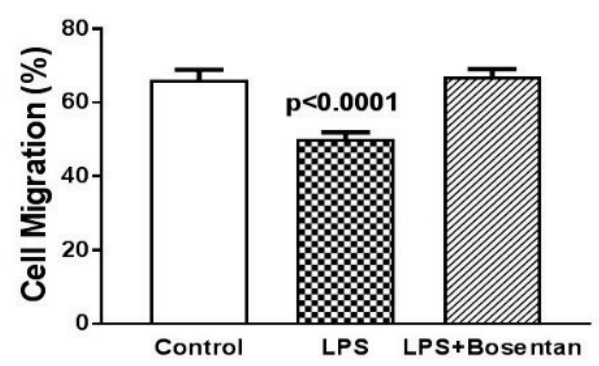

Fig. 7. ET receptor blockade with bosentan inhibit the LPS mediated necroptosis pathway in BMVECs. Expression of a) TLR-4 protein expression was upregulated with LPS $(100 \mathrm{ng} / \mathrm{ml})$, while pre incubation of cell with bosentan $(10 \mu \mathrm{M} ; 20$ min prior to LPS addition) inhibited the LPS mediated upregulation of TLR-4 (* $p=0.01$ vs. control, $n=4-6$ ). Downstream proteins in TLR-4 pathways, b) Myd88 and $\mathbf{c}$ ) phospho-RIPK3 were also upregulated with the LPS treatment whereas, inhibition of ET receptor with bosentan mitigated it ( $* \mathrm{p}=0.01$ and 0.002 , respectively, vs. control, $\mathrm{n}=4-6)$. d) LPS treatment reduced the cell migration property of BMVECs, while inhibition of ET receptor with bosentan improved it $(* p<0.0001, n=4-6)$.

\section{Discussion}

Vascular endothelial cells are important for maintenance of structural and functional homeostasis of the neurovascular unit and BBB. While ET-1 has been shown to mediate pathological remodeling and neovascularization in the cerebrovasculature, its effect on cell survival and death may vary depending on cell type, vascular bed and disease conditions. Thus, it becomes relevant to determine the impact of ET-1 on BMVEC 
survival and death. In the current study, we observed that under normal growth conditions, exogenous ET-1 stimulation shows a dose dependent effect on BMVECs: 1) Low $(10 \mathrm{nM})$ and moderate $(100 \mathrm{nM})$ concentrations of ET-1 retain cell viability while a pharmacological high dose of $1 \mu \mathrm{M}$ ET-1 reduces it. 2) Angiogenic property as measured by cell migration is also maintained with low and moderate dose of ET-1, while high dose inhibits the cell migration. 3) These changes are concomitant with the inhibition and activation of necroptotic and apoptotic gene expression at physiological lower doses and high dose, respectively. 4) On the other hand, in inflammatory conditions mimicked by LPS, even when endogenous ET-1 production is low, blockade of ET receptors with bosentan improves the cell viability and migration while reducing necroptosis suggesting that under disease microenvironment ET-1 can exert differential effects.

PCD is fundamental feature of cells devoted to maintenance of cellular structures and homeostasis of body. Most extensively studied form of PCD is apoptosis. It is characterized by cell shrinkage, plasma membrane blebbing, nuclear condensation and DNA fragmentation. It is associated with minimal inflammation and mainly facilitate cell elimination and cell-corpus removal (Danial et al. 2004). Apoptosis is mediated by a group of specialized protein cleaving enzymes caspases (Thornberry 1998). Apoptotic caspases are broadly divided in two groups, first initiator caspases (caspase 8-9) and second effector caspases (caspase 3-7) (Salvesen et al. 2011). A second prominent form of PCD is necroptosis. Like necrosis, necroptosis is characterized by cell and its organelles swelling and by consequent cell implosion. Unlike necrosis, necroptosis is triggered by programmed upstream molecular pathways (Christofferson et al. 2010, Tait et al. 2008). The signaling pathway that initiates necroptosis is well defined with TNF $\alpha$ and TNFR1. In addition, damage associated molecular patterns (DAMPs) like LPS and viral nucleic acid products and their receptors like toll like receptors, NOD like receptors and viral DNA receptors can also trigger the necroptotic signaling (Kaiser et al. 2013, Vanlangenakker et al. 2012). Another iron dependent form of programmed regulated cell death is called ferroptosis (Dixon et al. 2012). It involves iron catalyzed lipid damage. Although, the PCD mechanisms are well studied in immune and cancer cells, its regulation in BMVECs especially under inflammatory conditions are not explored. Our results show that necroptosis but no other PCD pathways are activated in these cells with concomitant activation of TLR4.

ET-1 has the ability to modulate PCD. It has anti-apoptotic actions on cardiac myocytes, renal carcinoma, ovarian carcinoma and prostrate epithelial cells (DeBosch et al. 2006, Del Bufalo et al. 2002, Pflug et al. 2007). ET-1 upregulation increases hepatocellular carcinoma cell proliferation, migration, progression and inhibit apoptosis ( $\mathrm{Lu}$ et al. 2012). Incubation of serum starved fibroblast or aortic endothelial cells with ET-1 prevents apoptosis (Shichiri et al. 1998a,b). Within the brain, reduced ET-1 level was associated with increased NLRP3 inflammasome formation in hippocampal neurons (Ward et al. 2016). On the other hand, ET-1 mediates glutamate induced retinal cell death (Kobayashi et al. 2005) and $\mathrm{ET}_{\mathrm{B}}$ receptor inhibition prevents neuronal apoptotic cell death (Siren et al. 2002, Yagami et al. 2002), while dual inhibition of ET receptors inhibits the ischemia induced necrosis (Hvaal et al. 1999). However, regulation of PCD by ET system in BMVECs is not established. Based on these evidences, our first objective was to determine the effect of exogenous ET-1 treatment on BMVEC survival under normal growth conditions. We observed that mild to moderate levels of ET-1 was not detrimental for cell viability and cell migration of BMVECs and in fact, inhibited the necroptosis (RIPK-3) and apoptosis (caspase-3) marker genes. Whereas a high concentration of ET-1 that is more representative of a pharmacological dose seems to have detrimental effect on BMVECs. We observed that high ET-1 decreases the cell viability and migration and it triggered the activation of necroptotic and apoptotic gene expression. Previous findings by Shichiri et al. (1998a,b), in serum starved aortic endothelial cells also support the observation that ET-1 has pro-survival effects. They demonstrated that ET-1 act as an autocrine/paracrine survival factor for endothelial cells (Shichiri et al. 1998a,b). While, another study reported incubation of HUVECs with ET-1 for $24 \mathrm{~h}$ activated apoptosis through $\mathrm{ET}_{\mathrm{B}}$ receptor mediated ROS generation (Dong et al. 2005). Observed activation of necroptosis not apoptosis in $6 \mathrm{~h}$ suggests ET-1 has time dependent regulation of RCD in BMVECs.

Under inflammatory and endotoxemic stress conditions, ET-1 mediated effects are disrupted and shifted towards a potent and longer lasting vasoconstriction (Baveja et al. 2002a,b). Studies have shown that LPS induces apoptosis in different types of endothelial cells including HUVEC and lung-derived normal human microvascular endothelial cells (Choi et al. 1998, Frey et al. 1998, Haimovitz-Friedman et al. 
1997, Koide et al. 1996, Yokochi et al. 1998). LPS release into the circulation induces endothelial apoptosis in vivo and thus causes microvascular injury (Hotchkiss et al. 1999). It is also reported that LPS pretreatment significantly inhibit ET-1 mediated eNOS activation. These evidences tempted us to use LPS to mimic inflammatory conditions and investigate the involvement of the ET system in RCD in this setting. We observed the activation of necroptosis marker genes as well as proteins after LPS treatment. However, we did not observe a difference in apoptotic marker gene after $6 \mathrm{~h}$ of LPS treatment. ET-1 measured in media was significantly reduced and it was accompanied with increase in expression of $\mathrm{ET}_{\mathrm{B}}$ receptor proteins in BMVECs cell lysate. While, blocking of ET receptors with bosentan inhibited the necroptosis pathway and improved the cell migration ability.

There are several limitations that must be discussed. In the current study only LPS was used to trigger PCD. Thus, it becomes important to test the response of BMVECs with other apoptotic, necroptosis activators and even use the BMVECs from disease models. Another limitation of current study is the use of single PCD marker gene. Screening of a number of apoptotic, necroptosis and ferroptosis marker genes would have strengthen the findings. Typically, only the $\mathrm{ET}_{\mathrm{B}}$ receptor has been reported on endothelial cells. However, an early study demonstrated the presence of the $\mathrm{ET}_{\mathrm{A}}$ subtype in brain endothelial cells (Kawai et al. 1997). In this study, we also detected this receptor subtype in BMVECs. Since, both $\mathrm{ET}_{\mathrm{A}}$ and $\mathrm{ET}_{\mathrm{B}}$ receptors are found on BMVECs, selective blocking of each receptor in future studies can provide further information on ET-1-mediated regulation of PCD mechanisms.

In conclusion, our findings suggest that ET-1 mediated cell survival and cell migration responses depend on the microenvironment. While ET-1 reduces viability only at high pharmacological conditions under normal growth conditions, even low levels of ET-1 can promote necroptosis under inflammatory conditions. Thus, we conclude that BMVECs are an early target in disease states and better understanding of the cell survival/death properties can identify mechanisms to improve endothelial function and integrity. The current study is first one to address the role of the ET system on PCD in BMVECs setting the platform for future studies in the area of PCD regulation by ET-1 in the microvasculature.

\section{Conflict of Interest}

There is no conflict of interest.

\section{Acknowledgements}

$\mathrm{AE}$ is a Research Career Scientist at the Charlie Norwood Veterans Affairs Medical Center in Augusta, Georgia. This work was supported in part by a Veterans Affairs (VA) Merit Award (BX000347), VA Research Career Scientist Award and National Institutes of Health (NIH) awards (R01NS083559, PO1HL128207) to AE and American Heart Association Predoctoral Fellowship to RW (17PRE33660400). The contents do not represent the views of the Department of Veterans Affairs or the US Government.

\section{References}

ABDELSAID M, MA H, COUCHA M, ERGUL A: Late dual endothelin receptor blockade with bosentan restores impaired cerebrovascular function in diabetes. Life Sci 118: 263-267, 2014.

BAVEJA R, KRESGE N, ASHBURN JH, KELLER S, YOKOYAMA Y, SONIN N, ZHANG JX, HUYNH T, CLEMENS MG: Potentiated hepatic microcirculatory response to endothelin-1 during polymicrobial sepsis. Shock 18: 415-422, 2002a.

BAVEJA R, YOKOYAMA Y, KORNESZCZUK K, ZHANG JX, CLEMENS MG: Endothelin 1 impairs oxygen delivery in livers from LPS-primed animals. Shock 17: 383-388, $2002 \mathrm{~b}$.

BEGLEY DJ, BRIGHTMAN MW: Structural and functional aspects of the blood-brain barrier. Prog Drug Res 61: 39-78, 2003.

CHEN DD, DONG YG, YUAN H, CHEN AF: Endothelin 1 activation of endothelin A receptor/NADPH oxidase pathway and diminished antioxidants critically contribute to endothelial progenitor cell reduction and dysfunction in salt-sensitive hypertension. Hypertension 59: 1037-1043, 2012.

CHOI KB, WONG F, HARLAN JM, CHAUDHARY PM, HOOD L, KARSAN A: Lipopolysaccharide mediates endothelial apoptosis by a FADD-dependent pathway. J Biol Chem 273: 20185-20188, 1998. 
CHRISTOFFERSON DE, YUAN J: Necroptosis as an alternative form of programmed cell death. Curr Opin Cell Biol 22: 263-268, 2010.

CIFARELLI V, LEE S, KIM DH, ZHANG T, KAMAGATE A, SLUSHER S, BERTERA S, LUPPI P, TRUCCO M, DONG HH: FOXO1 mediates the autocrine effect of endothelin-1 on endothelial cell survival. Mol Endocrinol 26: 1213-1224, 2012.

CIPOLLA MJ: The Cerebral Circulation. San Rafael (CA): Morgan and Claypool Life Sciences, 2009.

DANIAL NN, KORSMEYER SJ: Cell death: critical control points. Cell 116: 205-219, 2004.

DEBOSCH B, TRESKOV I, LUPU, TS, WEINHEIMER C, KOVACS A, COURTOIS M, MUSLIN AJ: Akt1 is required for physiological cardiac growth. Circulation 113: 2097-2104, 2006.

Del BufAlO D, Di CASTRO V, BIROCCIO A, VARMi M, SALANI D, ROSANO L, TRISCIUQLiO D, SPINEALLA F, BAGNATO A: Endothelin-1 protects ovarian carcinoma cells against paclitaxel-induced apoptosis: requirement for Akt activation. Mol Pharmacol 61: 524-532, 2002.

DIXON SJ, LEMBERG KM, LAMPRECHT MR, SKOUTA R, ZAITSEV EM, GLEASON CE, PATEL DN, BAUER AJ, CANTLEY AM, YANG WS, MORRISON B, STOCKWELL BR: Ferroptosis: an iron-dependent form of nonapoptotic cell death. Cell 149: 1060-1072, 2012.

DONG F, ZHANG X, WOLD LE, REN Q, ZHANG Z, REN J: Endothelin-1 enhances oxidative stress, cell proliferation and reduces apoptosis in human umbilical vein endothelial cells: role of ET(B) receptor, NADPH oxidase and caveolin-1. Br J Pharmacol 145: 323-333, 2005.

FREY EA, FINLAY BB: Lipopolysaccharide induces apoptosis in a bovine endothelial cell line via a soluble CD14 dependent pathway. Microb Pathog 24: 101-109, 1998.

HAIMOVITZ-FRIEDMAN A, CORDON-CARDO C, BAYOUMY S, GARZOTTO M, MCLOUGHLIN M, GALLILY R, EDWARDS CK, SCHUCHMAN EH, FUKS Z, KOLESNICK R: Lipopolysaccharide induces disseminated endothelial apoptosis requiring ceramide generation. $J$ Exp Med 186: 1831-1841, 1997.

HOTCHKISS RS, SWANSON PE, FREEMAN BD, TINSLEY KW, COBB JP, MATUSCHAK GM, BUCHMAN TG, KARL IE: Apoptotic cell death in patients with sepsis, shock, and multiple organ dysfunction. Crit Care Med 27: 1230-1251, 1999.

HVAAL K, MATHISEN SR, SVINDLAND A, NORDSLETTEN L, SKJELDAL S: Protective effect of the endothelin antagonist Bosentan against ischemic skeletal muscle necrosis. Acta Orthop Scand 70: 293-297, 1999.

IADECOLA C: The neurovascular unit coming of age: a journey through neurovascular coupling in health and disease. Neuron 96: 17-42, 2017.

KAISER WJ, UPTON JW, MOCARSKI ES: Viral modulation of programmed necrosis. Curr Opin Virol 3: 296-306, 2013.

KAWAI N, YAMAMOTO T, YAMAMOTO H, MCCARRON RM, SPATZ M: Functional characterization of endothelin receptors on cultured brain capillary endothelial cells of the rat. Neurochem Int 31: 597-605, 1997.

KOBAYASHI T, OKU H, FUKUHARA M, KOJIMA S, KOMORI A, ICHIKAWA M, KATSUMURA K, KOBAYASHI M, SUGIYAMA T, IKEDA T: Endothelin-1 enhances glutamate-induced retinal cell death, possibly through ET(A) receptors. Invest Ophthalmol Vis Sci 46: 4684-4690, 2005.

KOIDE N, ABE K, NARITA K, KATO Y, SUGIYAMA T, JIANG GZ, YOKOCHI T: Apoptotic cell death of vascular endothelial cells and renal tubular cells in the generalized Shwartzman reaction. FEMS Immunol Med Microbiol 16: 205-211, 1996.

LINKERMANN A, GREEN DR: Necroptosis. N Engl J Med 370: 455-465. 2014.

LU JW, HSIA Y, YANG WY, LIN YI, LI CC, TSAI TF, CHANG KW, SHIEH GS, TSAI SF, WANG HD, YUH CH: Identification of the common regulators for hepatocellular carcinoma induced by hepatitis B virus $\mathrm{X}$ antigen in a mouse model. Carcinogenesis 33: 209-219, 2012.

MORBIDELLI L, ORLANDO C, MAGGI CA, LEDDA F, ZICHE M: Proliferation and migration of endothelial cells is promoted by endothelins via activation of ETB receptors. Am J Physiol 269: 686-695, 1995.

OGATA Y, TAKAHASHI M, UENO S, TAKEUCHI K, OKADA T, MANO H, OOKAWARA S, OZAWA K, BERK BC, IKEDA U, SHIMADA K, KOBAYASHI E: Antiapoptotic effect of endothelin-1 in rat cardiomyocytes in vitro. Hypertension 41: 1156-1163, 2003. 
PFLUG BR, ZHENG H, UDAN MS, D'ANTONIO JM, MARSHALL FF, BROOKS JD, NELSON JB: Endothelin-1 promotes cell survival in renal cell carcinoma through the ET(A) receptor. Cancer Lett 246: 139-148, 2007.

SALANI D, DI CASTRO V, NICOTRA MR, ROSANO L, TECCE R, VENUTI A, NATALI PG, BAGNATO A: Role of endothelin-1 in neovascularization of ovarian carcinoma. Am J Pathol 157: 1537-1547, 2000.

SALVESEN G S, ASHKENAZI A: Snapshot: caspases. Cell 147: 476-476, 2011.

SHICHIRI M, MARUMO F, HIRATA Y: Endothelin-B receptor-mediated suppression of endothelial apoptosis. J Cardiovasc Pharmacol 31 (Suppl 1): S138-S141, 1998a.

SHICHIRI M, SEDIVY JM, MARUMO F, HIRATA Y: Endothelin-1 is a potent survival factor for c-Myc-dependent apoptosis. Mol Endocrinol 12: 172-180, 1998 b.

SIREN AL, LEWCZUK P, HASSELBLATT M, DEMBOWSKI C, SCHILLING L, EHRENREICH H: Endothelin B receptor deficiency augments neuronal damage upon exposure to hypoxia-ischemia in vivo. Brain Res 945 : 144-149, 2002.

TAIT SW, GREEN DR: Caspase-independent cell death: leaving the set without the final cut. Oncogene 27: 6452-6461, 2008.

THORNBERRY NA: Caspases: key mediators of apoptosis. Chem Biol 5: R97-R103, 1998.

VANLANGENAKKER N, VANDEN BERGHE T, VANDENABEELE P: Many stimuli pull the necrotic trigger, an overview. Cell Death Differ 19: 75-86, 2012.

WAGNER OF, CHRIST G, WOJTA J, VIERHAPPER H, PARZER S, NOWOTNY PJ, SCHNEIDER B, WALDHAUSL W, BINDER BR: Polar secretion of endothelin-1 by cultured endothelial cells. J Biol Chem 267: 16066-16068, 1992.

WARD R, ERGUL A: Relationship of endothelin-1 and NLRP3 inflammasome activation in HT22 hippocampal cells in diabetes. Life Sci 159: 97-103, 2016.

XIE Y, HOU W, SONG X, YU Y, HUANG J, SUN X, KANG R, TANG D: Ferroptosis: process and function. Cell Death Differ 23: 369-379, 2016.

YAGAMI T, UEDA K, ASAKURA K, KURODA T, HATA S, SAKAEDA T, KAMBAYASHI Y, FUJIMOTO M: Effects of endothelin B receptor agonists on amyloid beta protein (25-35)-induced neuronal cell death. Brain Res 948: 72-81, 2002.

YOKOCHI T, MORIKAWA A, KATO Y, SUGIYAMA T, KOIDE N: Apoptotic cell death in response to LPS. Prog Clin Biol Res 397: 235-242, 1998.

YU H, GUO P, XIE X, WANG Y, CHEN G: Ferroptosis, a new form of cell death, and its relationships with tumourous diseases. J Cell Mol Med 21: 648-657, 2017. 